\title{
Article
}

\section{The impact of education and training interventions for nurses and other health care staff involved in the delivery of stroke care: An integrative review}

Jones, Stephanie, Miller, Colette, Gibson, Josephine, Cook Lucas, Julie, Price, Chris and Watkins, Caroline Leigh

Available at http://clok.uclan.ac.uk/21064/

Jones, Stephanie ORCID: 0000-0001-9149-8606, Miller, Colette ORCID: 00000003-0620-6029, Gibson, Josephine ORCID: 0000-0002-3051-1237, Cook Lucas, Julie ORCID: 0000-0002-6391-5430, Price, Chris and Watkins, Caroline Leigh ORCID: 0000-0002-9403-3772 (2018) The impact of education and training interventions for nurses and other health care staff involved in the delivery of stroke care: An integrative review. Nurse Education Today, 61 . pp. 249-257. ISSN 0260-6917

It is advisable to refer to the publisher's version if you intend to cite from the work. http://dx.doi.org/10.1016/j.nedt.2017.11.024

For more information about UCLan's research in this area go to http://www.uclan.ac.uk/researchgroups/ and search for <name of research Group>.

For information about Research generally at UCLan please go to http://www.uclan.ac.uk/research/

All outputs in CLoK are protected by Intellectual Property Rights law, including Copyright law. Copyright, IPR and Moral Rights for the works on this site are retained by the individual authors and/or other copyright owners. Terms and conditions for use of this material are defined in the policies page. 


\section{Accepted Manuscript}

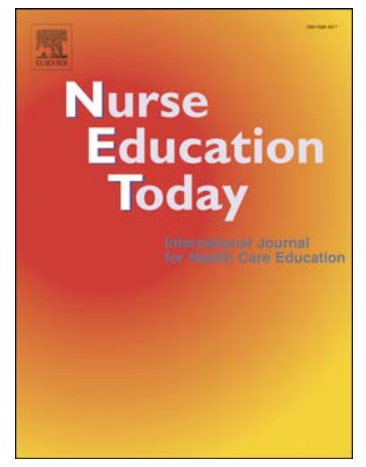

The impact of education and training interventions for nurses and other health care staff involved in the delivery of stroke care: An integrative review

Stephanie P. Jones, Colette Miller, Josephine M.E. Gibson, Julie Cook, Chris Price, Caroline L. Watkins

PII:

S0260-6917(17)30284-8

DOI: $\quad$ doi: $10.1016 /$ j.nedt.2017.11.024

Reference: $\quad$ YNEDT 3672

To appear in: $\quad$ Nurse Education Today

Received date: 31 October 2016

Revised date: $\quad 24$ October 2017

Accepted date: $\quad 20$ November 2017

Please cite this article as: Jones, Stephanie P., Miller, Colette, Gibson, Josephine M.E., Cook, Julie, Price, Chris, Watkins, Caroline L., The impact of education and training interventions for nurses and other health care staff involved in the delivery of stroke care: An integrative review, Nurse Education Today (2017), doi:10.1016/j.nedt.2017.11.024

This is a PDF file of an unedited manuscript that has been accepted for publication. As a service to our customers we are providing this early version of the manuscript. The manuscript will undergo copyediting, typesetting, and review of the resulting proof before it is published in its final form. Please note that during the production process errors may be discovered which could affect the content, and all legal disclaimers that apply to the journal pertain. 
THE IMPACT OF EDUCATION AND TRAINING INTERVENTIONS FOR NURSES AND OTHER HEALTH CARE STAFF INVOLVED IN THE DELIVERY OF STROKE CARE: AN INTEGRATIVE REVIEW

\section{Authors' names and affiliations}

Stephanie P Jones (CA) ${ }^{1}$ Senior Research Fellow PhD, MA, PGCert, BA (Hons).Tel. 01772 895107. Fax. 01772 894545. E-mail. sjones10@uclan.ac.uk.

Colette Miller ${ }^{1}$ Senior Research Assistant BSc (Hons). E-mail. Tel. 01772 893693. Fax. 01772894545. Cmiller5@uclan.ac.uk.

Josephine ME Gibson ${ }^{1}$ Senior Lecturer (Research) PhD, MSc, BSc (Hons), RGN. Tel. 01772895144. Fax. 01772 894545. E-mail. Jgibson4@uclan.ac.uk.

Julie Cook ${ }^{1}$ Research Associate BA (Hons). E-mail. Tel. 01772 892549. Fax. 01772894545.

JCook11@uclan.ac.uk

Chris Price ${ }^{2}$ Consultant Physician (Stroke Medicine) and Clinical Senior Lecturer FRCP, Masters in Clinical Education, MD, MRCP, MB ChB. E-mail. Tel. 0191208 6779. C.I.M.Price@newcastle.ac.uk. Caroline L Watkins ${ }^{1}$ College Director of Research \& Innovation PhD, BA (Hons), SRN. Tel. 01772 893646. Fax.01772 894545.E-mail. clwatkins@uclan.ac.uk.

${ }^{1}$ University of Central Lancashire, Clinical Practice Research Unit, Brook Building, Preston, UK ${ }^{2}$ Newcastle University, Newcastle Upon Tyne, UK

\section{Contributions of authors}

Dr Stephanie Jones (Research Fellow, University of Central Lancashire): substantial contributions to the design and methodology, advised on the data extraction and data analysis. Contributed to the writing, revision and approval of the final paper. 
Dr Josephine Gibson (Senior Lecturer, University of Central Lancashire): advised on the data extraction and data analysis. Contributed to the writing, revision and approval of the final paper. Colette Miller (Research Assistant, University of Central Lancashire): substantial contributions to the search strategy, data extraction and data analysis. Contributed to the writing, revision and approval of the final paper.

Julie Cook Lucas (Research Associate, University of Central Lancashire): advised on the data extraction and data analysis. Contributed to the writing, revision and approval of the final paper. Dr Chris Price (Clinical Senior Lecturer in Medicine, Newcastle University): substantial contributions to the design and methodology. Contributed to the writing, revision and approval of the final paper. Professor Caroline Watkins (Professor of Stroke and Older People's Care, University of Central Lancashire): substantial contributions to the design and methodology, advised on the data extraction and data analysis. Contributed to the writing, revision and approval of the final paper.

Word count: 3281

\section{Acknowledgements}

Funding for this review was provided by the Stroke Association.

\section{Abstract}

\section{Objectives}

The aim of this review was to explore the impact of stroke education and training of nurses and other health care staff involved in the delivery of stroke care. 
Design

We performed an integrative review, following PRISMA guidance where possible.

\section{Data sources}

We searched MEDLINE, ERIC, PubMed, AMED, EMBASE, HMIC, CINAHL, Google Scholar, IBSS, Web of Knowledge, and the British Nursing Index) from 1980 to 2016.

\section{Review methods}

Any intervention studies were included if they focused on the education or training of nurses and other health care staff in relation to stroke care. Articles that appeared to meet the inclusion criteria were read in full. Data were extracted from the articles, and the study quality assessed by two researchers. We assessed risk of bias of included studies using a pre-specified tool based on Cochrane guidance.

\section{Results}

Our initial search identified 2850 studies of which 21 met the inclusion criteria. Six studies were randomised controlled trials, and one was an interrupted time series. Fourteen studies were quasiexperimental: eight were pretest-posttest; five were non-equivalent groups; one study had a single assessment. Thirteen studies used quality of care outcomes and eight used a patient outcome measure. None of the studies was identified as having a low risk of bias. Only nine studies used a multi-disciplinary approach to education and training and nurses were often taught alone. Interactive education and training delivered to multi-disciplinary stroke teams, and the use of protocols or guidelines tended to be associated with a positive impact on patient and quality of care outcomes. 


\section{Conclusions}

Practice educators should consider the delivery of interactive education and training delivered to multi-disciplinary groups, and the use of protocols or guidelines, which tend to be associated with a positive impact on both patient and quality of care outcomes. Future research should incorporate a robust design. 


\section{BACKGROUND}

Stroke is a leading cause of mortality and disability worldwide ${ }^{1}$ and is recognised as a timedependent medical emergency in which early presentation to specialist care reduces death and dependency ${ }^{2}$. Stroke survivors are known to have complex needs ${ }^{3,4}$ with a commensurate requirement for knowledgeable and skilled rehabilitative and long-term support from appropriately trained staff. It has been demonstrated that the provision of care in a stroke unit improves outcomes for people who have experienced stroke ${ }^{5}$. The reasons for this are unclear, but are likely to be at least partly attributable to the presence of a multi-disciplinary team with specialised knowledge, skills and experience in stroke. The development and delivery of stroke-specific education is therefore of vital importance to the provision of high quality stroke care and to improve outcomes for people who have experienced stroke; to ensure this care from staff with the appropriate education and skills at all points on the stroke pathway (e.g. pre-hospital, emergency, rehabilitation, long-term care, and primary care).

In England, a report by the National Audit Office (NAO) highlighted that the limited number of health professionals with stroke-specific education and training could be a barrier to providing high-quality acute care and rehabilitation ${ }^{2}$. The National Stroke Strategy in England also highlighted the need for nationally recognised, quality assured and transferable education and training for stroke staff in order to ensure that the stroke workforce had appropriate knowledge and skills ${ }^{6}$. Consequently, a Stroke-Specific Education Framework (SSEF) was developed ${ }^{7}$. The SSEF consists of 16 elements of care, based on the quality markers in the National Stroke Strategy and related to the stroke strategies of all four UK countries, which cover the whole of the stroke care pathway. Each element contains key competencies, reflecting the knowledge and skills required by staff working in that area of stroke care delivery, that should be covered in any education and training package. 
A previous review of education and training with nurses in stroke found a paucity of evidence, which was limited to stroke rehabilitation settings ${ }^{8}$, and included only one study which directly examined the impact of education and training for nurses on outcomes of people who had experienced stroke $^{9}$. This before and after study found that whilst there were some improvements in clinical practice, there was no significant difference between the two groups for Barthel index, Hospital Anxiety and Depression scale, occurrence of secondary complications, length of stay or inpatient and carer satisfaction ${ }^{9}$.

As detailed in the National Stroke Strategy, stroke care extends prior to and after rehabilitation, which is only one of the key areas of the stroke pathway ${ }^{6}$. Moreover, a wide range of staff contribute to stroke care across the whole of the stroke pathway. If we are to fully understand the value of stroke education and training we need a comprehensive and systematic approach to synthesising relevant research evidence.

The aim of this review was to summarise the existing scientific literature exploring the impact of stroke education and training of nurses and other health care staff involved in the delivery of stroke care, using integrative review methodology. An integrative review utilises a systematic methodology for searching and appraisal to ensure that it is comprehensive and inclusive. However, unlike other systematic review approaches, integrative review enables the synthesis of research studies utilising diverse methodologies ${ }^{10}$.

Research questions:

1. What types of stroke education and training interventions have been developed for nurses and other health care staff?

2. How has the impact of stroke education and training been assessed? 
3. Is there evidence for the effectiveness of stroke education and training on quality of care or patient outcomes?

\section{$\underline{\text { DESIGN }}$}

Primary research studies, using any methodology, assessing the impact of stroke education and training were included if they described education and training in relation to stroke, of health care personnel (including: emergency medical dispatchers, paramedics, ambulance technicians, nurses, health care assistants, doctors, physiotherapists, occupational therapists, speech and language therapists, pharmacists, social workers, trainees and multi-disciplinary groups). Studies that focused solely on the education and training of people who have experienced stroke or informal supporters (carers) were not included.

Studies were included if they reported an evaluation of the impact of the education or training on a measure of patient care, in terms of either a patient or quality of care outcome measure. Patient outcomes were defined as those that related to health status or health behaviour. Other measures of health status included mortality or a marker of morbidity such as discharge destination. Quality of care outcomes were defined by the research team as those that related to quality or timeliness of patient care delivery. Where a primary outcome was explicitly stated by the study authors, this was taken as the main outcome of the study. Where no primary outcome was stated and multiple outcomes were reported, the research team designated the main outcome through consensus. If present, a patient outcome was considered to be the main outcome; otherwise a quality of care outcome was selected.

Studies were included from any country, if they were published in full and in English. 


\section{$\underline{\text { Data sources }}$}

A search strategy was developed (see Supporting Information), including the MeSH terms stroke, education, and health personnel. The search strategy was adapted to search a range of databases (MEDLINE, ERIC, PubMed, AMED, EMBASE, HMIC, CINAHL, Google Scholar, IBSS, Web of Knowledge, and the British Nursing Index) from 1980 to July 2016.

\section{Review methods}

Citations were initially screened on title and then abstract. This process was undertaken independently by two trained researchers (SJ and CM ). Any articles that met the inclusion criteria were read in full by two trained researchers (SJ, CM, JG, JL). Disagreements over the inclusion of any articles were discussed by the project steering group. Backward and forward citation searches were performed to test the quality of the search strategy.

\section{Assessment of risk of bias in included studies}

The inclusion of studies with varying methodologies required the development of a framework to assess study quality which could encompass a range of study designs. The Cochrane 'risk of bias' tool was used as the starting point to develop this method ${ }^{11}$. Selection, performance, detection, attrition and reporting biases were included in order to assess study quality.

\section{Data extraction and management}

We designed a data extraction form that summarised the following characteristics:

i. Study detail (author, year of publication, country of origin, study type);

ii. Staff participants (setting, professions, sample size);

iii. Type of education or training (content, format, method of delivery, by whom delivered, duration, frequency, barriers to implementation);

iv. Patient characteristics (stroke/TIA, sample size, age, sex); 
v. Outcomes (primary/main outcome measures categorised as patient outcomes or quality of care outcomes), main results, inferential and descriptive statistics;

vi. Risk of bias (selection, performance, detection, attrition, reporting).

Method of delivery was categorised into didactic (e.g. lectures, videos, CDs, workbooks, protocols, on-line), or interactive (e.g. action plans, practical sessions, reflective practice, workshops, feedback). Data extraction forms were piloted using three of the included studies. The accuracy of data extraction was checked by a second independent extractor for all included studies.

We did not contact the study authors for missing data or for clarification.

Included studies were mapped against the SSEF Elements of care ${ }^{7}$ to assess the breadth of stroke education and training delivery. The 16 elements are listed in Table 1 below.

Analysis

There was a great deal of heterogeneity between the study designs, the type and format of the education or training provided, and the outcomes reported, and therefore we were unable to perform a meta-analysis of the included randomised controlled trials. Consequently, we have described included studies narratively.

\section{RESULTS}

The search strategy initially identified 2850 articles. Following screening of the title, abstract or complete article, 21 studies met the inclusion criteria (see Figure 1).

Figure 1: Flow diagram. 


\section{$\underline{\text { Risk of bias }}$}

The proportion of studies demonstrating each type of bias can be seen in Figure 2 (Supporting Information). None of the studies was identified as having a low risk of bias across all five domains. Evidence for selection bias was unclear in a majority of studies, and two studies ${ }^{12-13}$ were at high risk of selection bias. Performance bias was evident in all studies, although this is not unreasonable given the nature of education and training in health care. Detection bias was unclear for many studies, but where bias could be assessed, in most cases there was a low risk; only one study ${ }^{13}$ had a high risk of detection bias. Evidence for attrition bias was unclear for the majority of studies. Two studies were at high risk for attrition bias ${ }^{14-15}$ while seven had a low risk ${ }^{12,16-21}$. The risk of reporting bias was unclear in one study, while the other 20 studies were evenly split between low and high risk.

\section{Narrative review}

Description of eligible studies

Of the 21 included studies, six used a randomised trial design: two ${ }^{12,21}$ were randomised controlled trials (RCTs), and four ${ }^{16,18,22-23}$ were cluster RCTs. One study was an interrupted time series ${ }^{24}$. The remaining studies used quasi-experimental designs: eight were pretest-posttest ${ }^{9,13,25-30}$, five were non-equivalent groups ${ }^{15,17,19,20,31}$ and one was a post-test study ${ }^{14}$. Details of study characteristics are summarised in Table 2. Only 12 studies reported the numbers of staff who received education and training (total 1,190, median 99, range 12 to 345 ). Over half the studies involved the education or training of nurses (57\%). All but one study ${ }^{25}$ reported the number of patients included in outcome measurements, which totalled 9,913 across 20 studies (median 495, range 37 to 1696). 
Of the 21 studies, 16 provided sufficient further detail to be able to categorise the method of education or training delivery (Table 3).

What types of stroke educational interventions have been developed for health care staff? Twelve studies $9,12-17,22,25,28,31$ entailed education or training programmes for a single health profession or occupational group. In most of these studies, nurses were the recipients of the education or

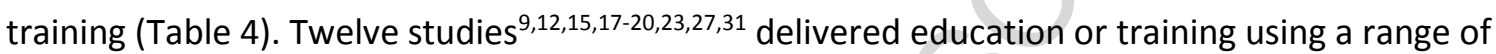
approaches including face-to-face lectures, videos, workshops, protocols and reflective practice. Four studies used a single method of delivery ${ }^{14,15,24,29}$, only one of which delivered an on-line course $^{24}$. The remaining studies did not state the method of delivery ${ }^{13,21,25,26,30}$. In those studies that reported the duration and/or frequency of education or training ${ }^{9,12,13,15,16,18,22-24,26-28,31}$, duration ranged from one hour to two working days, with most education or training sessions being delivered on one or two occasions.

In terms of the 16 Stroke-Specific Education Framework Elements of care, 12 studies focused on a single Element, of which seven were in specialist rehabilitation. Four studies focused on two Elements, four covered three Elements and one focused on five Elements. The included studies focused on urgent response $(n=9)$, acute stroke assessment $(n=6)$ and treatment $(n=3)$, and specialist rehabilitation ( $n=11$ ). There were fewer studies (two each) on seamless transfer of care, long-term care, and post-stroke review. No studies were identified on managing risk (in terms of primary prevention), information, user involvement, Treatment (TIA), end of life, participation in community, and return to work.

How has the impact of stroke education and training been assessed? Eighteen of the 21 studies specified a main outcome measure. The majority of studies ( $n=11)$ used a quality of care outcome. The remaining six studies specified a patient measure as their main 
outcome. The three remaining studies did not specify a primary outcome and had a main outcome designated by the research team for the purposes of this analysis. The main outcome measures were very diverse, with only three outcomes being assessed in more than one study: Identification of stroke ${ }^{13,24,28,30}$; thrombolysis rates ${ }^{19,20}$; patient position/posture ${ }^{9,15}$ (see Table 5 in Supporting Information).

Is there evidence for the effectiveness of stroke education and training on outcome?

Eleven (52\%) of the included studies reported a positive impact of education and training on patient or quality of care outcomes. Of the studies measuring patient outcomes none used the same outcome measure. Two of the studies that showed a positive impact on physical health utilised a cluster RCT design and provided interactive, mixed methods of delivery, but there were no further commonalities between the two studies ${ }^{18,23}$. Two further studies found a positive association between education and training and psychosocial ${ }^{17}$ and health behaviour ${ }^{12}$ outcomes, but again there were few commonalities between these studies. It is therefore difficult to assess adequately the extent to which education and training could lead to improved patient outcomes. Seven studies had a positive impact on quality of care outcomes. Of these studies, three related to the identification of stroke in pre-hospital settings ${ }^{13,24,30}$, two measured the impact of thrombolysis rates $^{19,20}$; whilst the remaining two papers looked at time to arrival at the Emergency Department ${ }^{26}$ and correct positioning ${ }^{15}$. Again, there were few commonalities between studies in terms of study design ( $\left(\mathrm{RCT}^{13}\right.$, Quasi experimental ${ }^{15,19,20}$, interrupted time-series ${ }^{24}$, pre-post intervention study ${ }^{26,30}$ ); staff groups (mixed ${ }^{19,20,26,30}$, nurses ${ }^{15}$, EMS dispatchers ${ }^{24}$, paramedics ${ }^{13}$ ); delivery mode (face-to-face practicals, protocols and feedback ${ }^{19,20}$, manual and workbook $^{15}$, on-line ${ }^{24}$, not stated ${ }^{13,26,30}$ ) and duration (one 4-hour session ${ }^{13}$, one 2-hour session ${ }^{15,24,26}$, not stated ${ }^{19,20,30}$ ). 


\section{DISCUSSION}

This is the first review that has systematically synthesised the published literature on the impact of stroke education and training of nurses and other health care staff involved in the delivery of stroke care. Two of the studies reported positive patient outcomes in relation to the modified Rankin scale ${ }^{18}$ and the Functional Independence Measure ${ }^{23}$. Both of these studies were considered high quality, utilising a cluster RCT design with lower risks of bias. One further study ${ }^{24}$ reported a positive impact on a quality of care outcome (dispatcher recognition of stroke) in an interrupted time series study, and also had a lower risk of bias. Eight further studies, which reported positive patient or quality of care outcomes, were of less robust study design or at higher risk of bias, or both. The remaining 10 studies did not demonstrate positive findings for their main outcome.

The impact of education and training on patient outcomes in stroke is unclear. Although four studies reported a positive impact of education and training on patient outcomes $12,17,18,23$ the strength of evidence was varied and none used the same outcome measure. There is a clearer picture when measuring the impact of education and training on quality of care outcomes. The results of these five studies suggest that the provision of education and training to improve recognition of stroke may lead to an increase in the identification of stroke by paramedics and call handlers ${ }^{13,24,30}$ and raising awareness of stroke and protocols for its treatment in the Emergency Department may increase thrombolysis rates ${ }^{19,20}$. However, there is limited evidence from two further studies that education and training may improve onset to arrival times and positioning or posture ${ }^{15,26}$.

The risk of bias varied across the included studies. The risk of attrition and selection bias was often unclear and could have been minimised by robust study design and reporting.

There were further limitations of the studies included. Methodologically, the 21 included studies all shared a common key limitation, in that none conducted comparisons of two or more methods of 
educational delivery in order to determine the most effective delivery method(s). Studies often had small sample sizes with high attrition rates and unrepresentative samples. Almost half of the included studies did not report the number of health care personnel that received education and training, and very few reported rates of uptake and/or completion of education and training. Studies varied in the quality of the information reported regarding the content, delivery and duration of the education and training programmes provided. However, the two most recent studies ${ }^{16,24}$ were both of higher quality. In numerous studies the educational programme was just one part of a multi-faceted intervention, of which education and training was only one component, making it difficult to evaluate the actual effectiveness of the education and training delivered.

Due to limited resources, only studies in the English language were included and authors of included studies were not contacted for clarification or further information. It is possible that some studies were excluded where they related to staff education and training in general settings (e.g. general medical or rehabilitation wards), where a proportion of the patients had had a stroke, but where study outcomes for people who had experienced stroke were not reported separately.

It is well established that stroke survivors whose care is provided by a multi-disciplinary team who specialise in stroke care are more likely to be alive, independent, and living at home one year after stroke $e^{5}$. It could be argued that an education and training programme that reflects the complex multi-disciplinary ethos of stroke care might be more effective in improving outcomes, than initiatives which focus on the delivery of profession-specific education and training for single staff groups. However, as reported in this review, only nine studies used a multi-disciplinary approach to education and training, and nurses in particular were often taught alone.

Continuing education and training in healthcare can be classified as a complex intervention ${ }^{32}$. As with any complex intervention, clearly defined implementation strategies may facilitate the 
systematic uptake of educational interventions, and fidelity practices may increase the degree to which the constituent components of an education and training intervention are delivered as planned ${ }^{33}$. It is necessary to conduct robust implementation research in order to translate findings across disciplines and settings. However, only eight studies considered the barriers to the implementation of education and training interventions, and there was a dearth of reporting of detailed implementation strategies. It is recommended that future educational interventions are underpinned with explicit theory that details implementation processes.

The included studies used a variety of delivery methods, with the majority using interactive teaching methods rather than taking a purely didactic approach. Although few studies discussed the theoretical underpinning of their educational approach, the prevalence of the use of interactive methods is consistent with andragogic teaching philosophies ${ }^{34}$. Such approaches are appropriate for programmes of adult learning with health care staff.

Recent advances in the use of information technology as a tool for facilitating student learning (elearning), particularly for those accessing courses from the practice setting ${ }^{35}$, have the potential to transform continuing professional development in health care. Only one study reported the use of e-learning, although this is unsurprising in relation to the older studies included in this review. In terms of the Stroke-Specific Education Framework Elements of care, the available evidence is dominated by studies of urgent response, acute stroke assessment and treatment, and specialist rehabilitation. There are few studies of seamless transfer of care, long-term care, and review, and no studies of managing risk, information, user involvement, treatment of TIA, end of life care, participation in community, and return to work. This dominance of the evidence base by studies in the pre-hospital, acute and rehabilitation stages of the stroke pathway, and lack of evidence in other aspects of stroke care, mirrors the distribution of research into stroke interventions themselves (not just educational interventions). 
The effectiveness of different approaches for delivery will be related to the content, learner group, setting and mode of evaluation. Therefore it is not possible to recommend a concise summary of interventions, as this would be an over simplification. However, structured summaries of strokerelated knowledge and skills, according to professional role, are available from the SSEF website http://www.stroke-education.org.uk/.

\section{Conclusions}

Education and training can improve outcomes for people who have experienced stroke. Practice educators should consider the delivery of interactive education and training delivered to multidisciplinary groups, and the use of protocols or guidelines which tend to be associated with a positive impact on both patient and quality of care outcomes. Although there were some studies that reported positive results, there was wide heterogeneity of design, interventions and outcomes. Future research should incorporate a robust design including publication of carefully selected patient and quality of care outcome measures, which reflect the educational intervention and facilitate future meta-analysis.

\section{Competing interests}

There are no competing interests to declare. 


\section{REFERENCES}

1. Lopez AD, Mathers CD, Ezzati M, Jamison DT, Murray CJL. Global and regional burden of disease and risk factors. 2001: systematic analysis of population health data. Lancet. 2006;367:1747-1757.

2. National Audit Office, Department of Health. Reducing Brain Damage: Faster access to better stroke care. London: The Stationery Office; 2005.

3. French B, Leathley M, Radford K, Dey P, McAdam J, Marsden J, et al. UK Stroke Survivor Needs Survey Information Mapping Exercise. Final report for The Stroke Association; 2008.

4. McKevitt C, Fudge N, Redfern J, Sheldenkar A, Crichton S, Rudd AR, Forster A, Young J, Nazareth I, Silver LE, Rothwell PM, Wolfe CDA. Self-reported long-term needs after stroke. Stroke. 2011;42:1398-1403.

5. Stroke Unit Trialists' Collaboration. Organised Inpatient (stroke unit) Care for Stroke (Cochrane Review). In: The Cochrane Library, Issue 1, 2013. doi: 10.1002/14651858.CD000197.pub3.

6. Department of Health. National Stroke Strategy. London: Department of Health; 2007.

7. Watkins C, Jenkinson D, Scoular P, Williams J, Fletcher M, Roffe C, Leathley M, Golton I on behalf of the UK Forum for Stroke Training. Stroke-Specific Education Framework (SSEF); 2009. Available at: http://webarchive.nationalarchives.gov.uk/20130107105354/http://www.dh.gov.uk/en/Pub 
licationsandstatistics/Publications/PublicationsPolicyAndGuidance/DH_098352?PageOperati on=email. Accessed November 11, 2014.

8. Edwards G. The training and education of nurses working in stroke care. British Journal of Nursing. 2006;15:1180-1184.

9. Forster A, Dowswell G, Young J, Sheard J, Wright P, Bagley P. Effects of a physiotherapist-led stroke training programme for nurses. Age and Ageing. 1999;28:567-574.

10. Whittemore R and Knafl K. The integrative review: updated methodology. JAN. 2005;52:54653.

11. Higgins JPT, Altman DG, Gotzsche PC, Juni P, Moher D, Oxman AD, Savovic J, Schulz KF, Weeks L, Sterne JAC. The Cochrane Collaboration's tool for assessing risk of bias in randomised trials. BMJ. 2011;343 doi: 10.1136/bmj.d5928.

12. Nir Z, Weisel-Eichler A. Improving knowledge and skills for use of medication by patients after stroke: Evaluation of a nursing intervention. Am J Phys Med Rehabil. 2006;85(7):582592.

13. Smith W, Curry M, Fazackerley J, Isaacs M. Improved paramedic sensitivity in identifying stroke victims in the prehospital setting. Prehospital Emergency Care. 1999;3:207-210.

14. Herr-Wilbert I, Imhof L, Hund-Georgiadis M, Wilbert D. Assessment-guided therapy of urinary incontinence after stroke. Rehabilitation Nursing. 2010;35(6):248-253.

15. Jones A, Carr E, Newham D, Wilson-Barnett J. Positioning of stroke patients: Evaluation of a teaching intervention with nurses. Stroke. 1998;29:1612-1617. 
16. Forster A, Dickerson J, Young J, Patel A, Kalra L, Nixon J, Smithard D, Knapp M, Holloway I, Anwar S, Farrin A. A structured training programme for caregivers of inpatients after stroke (TRACS): a cluster randomised controlled trial and cost-effectiveness analysis. Lancet. 2013;382:2069-2076.

17. Hohmann C, Klotz J, Radziwill R, Jacobs A, Kissel T. Pharmaceutical care for patients with ischemic stroke: improving the patients quality of life. Pharmacy world \& Science. 2009;31(5):550-558.

18. Middleton S, McElduff P, Ward J, Grimshaw J, Dale S, D'este C, Drury P, Griffiths R, Cheung N, Quinn C, Evans M, Cadilhac D, Levi C. Implementation of evidence-based treatment protocols to manage fever, hyperglycaemia, and swallowing dysfunction in acute stroke (QASC): a cluster randomised controlled trial. Lancet. 2011;378:1699-1706.

19. Morgenstern L, Staub L, Chan W, Wein T, Bartholomew K, King M, Felberg R, Burgin S, Groff J, Hickenbottom S, Saldin K, Demchuk A, Kalra A, Dhingra A, Grotta J. Improving delivery of acute stroke therapy: The TLL Temple Foundation Stroke Project. Stroke. 2002;33:160-166.

20. Morgenstern L, Bartholomew K, Grotta J, Staub L, King M, Chan W. Sustained benefit of a community and professional intervention to increase acute stroke therapy. Archives of Internal Medicine. 2003;163:2198-2202.

21. Nikopoulou-Smyrni P, Nikopoulos C. A new integrated model of clinical reasoning: Development, description and preliminary assessment in patients with stroke. Disabil. Rehabil. 2007;29(14):1129-1138. 
22. Jones A, Tilling K, Wilson-Barnett J, Newham D, Wolfe C. Effect of recommended positioning on stroke outcome at six months: a randomized controlled trial. Clinical Rehabilitation. 2005;19:138-145.

23. Strasser D, Falconer J, Stevens A, Uomoto J, Herrin J, Bowen S, Burridge A. Team training and stroke rehabilitation outcomes: A cluster randomized trial. Archives of Physical Medicine and Rehabilitation. 2008;89;10-15.

24. Watkins C, Leathley M, Jones S, Ford G, Quinn T, Sutton C. Training emergency services' dispatchers to recognise stroke: an interrupted time-series analysis. BMC Health Services Research. 2013;13;318.

25. Amato S, Salter J, Mion L. Physical restraint reduction in the acute rehabilitation setting: A quality improvement study. Rehabilitation Nursing. 2006;31(6):235-241.

26. Behrens S, Daffertshofer M, Interthal C, Ellinger J, Van Ackern K, Hennerici M. Improvement in stroke quality management by an educational programme. Cerebrovascular Diseases. 2002;13(4):262-266.

27. De Luca A, Caprara A, Barbolini M, Francia C, Ferri M, Mamede S, Borgia P, Guasticchi G. Continuing medical education and evidence-based clinical pathways. Training emergency health workers in Latium, Italy. Education for Health. 2008;21(1):119.

28. Frendl D, Strauss D, Underhill B, Goldstein L. Lack of impact of paramedic training and use of the Cincinnati prehospital stroke scale on stroke patient identification and on-scene time. Stroke. 2009;40:754-756. 
29. Kavanagh D, Connolly P, Cohen J. Promoting evidence-based practice: Implementing the American Stroke Association's acute stroke program. Journal of Nursing Care Quality. 2006;21(2):135-142.

30. Wojner-Alexandrov A, Alexandrov A, Rodriguez D, Persse D, Grotta J. Houston paramedic and emergency stroke treatment and outcomes study (HoPSTO). Stroke. 2005;36:1512-1518.

31. Booth J, Hillier V, Waters K, Davidson I. Effects of a stroke rehabilitation education programme for nurses. Journal of Advanced Nursing. 2005;49(5):465-473.

32. Mattick K, Barnes R, Dieppe P. Medical education: a particularly complex intervention to research. Advanced Health Science Education Theory and Practice. 2013;18(4):769-78.

33. Campbell M, Fitzpatrick R, Haines A, Kinmonth AL, Sandercock $P$, Spiegelhalter D, Tyrer P. Framework for design and evaluation of complex interventions to improve health. British Medical Journal. 2000;16:321:694-696.

34. Khan KS and Coomarasamy A. A hierarchy of effective teaching and learning to acquire competence in evidenced-based medicine. BMC Medical Education. 2006;6:59 doi:10.1186/1472-6920-6-59.

35. Blake H. Staff perceptions of e-learning for teaching delivery in healthcare. Learning in Health and Social Care. 2009;8:223-234. 
Figure 1. Flow diagram of included studies

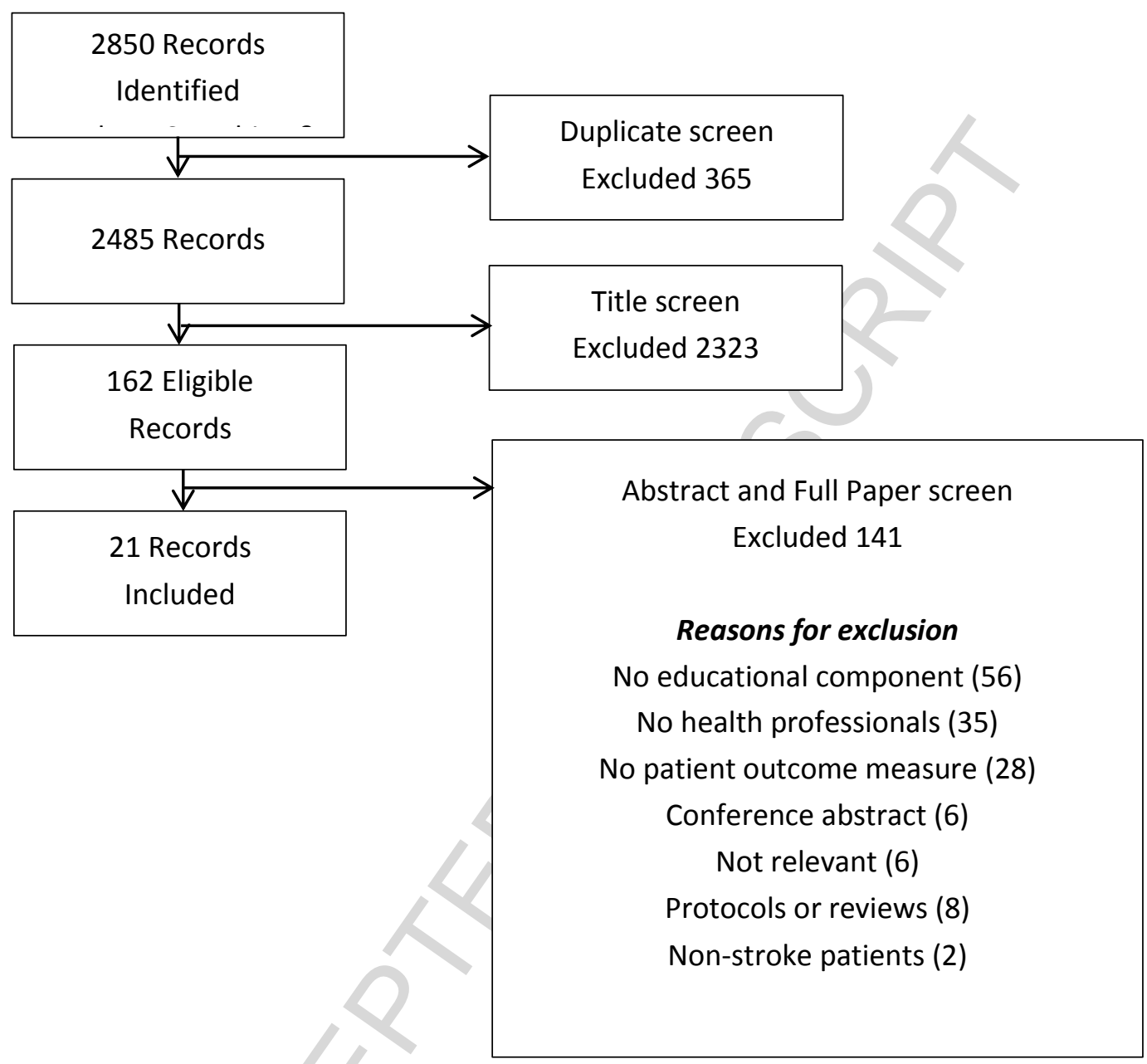


Figure 2. Risk of bias

\begin{tabular}{|c|c|c|c|c|c|}
\hline & $\begin{array}{l}\text { Selection } \\
\text { bias }\end{array}$ & $\begin{array}{l}\text { Performance } \\
\text { bias }\end{array}$ & $\begin{array}{l}\text { Detection } \\
\text { bias }\end{array}$ & $\begin{array}{l}\text { Attrition } \\
\text { bias }\end{array}$ & $\begin{array}{l}\text { Reporting } \\
\text { bias }\end{array}$ \\
\hline Amato 2006 & Unclear & High & Unclear & Unclear & High \\
\hline Behrens 2002 & Unclear & High & Unclear & Unclear & High \\
\hline Booth 2005 & Unclear & High & Unclear & Low & High \\
\hline DeLuca 2008 & Unclear & High & Unclear & Unclear & High \\
\hline Forster 1999 & Unclear & High & Unclear & Unclear & Unclear \\
\hline Forster 2013 & Unclear & High & Low & Unclear & Low \\
\hline Frendl 2009 & Unclear & High & Unclear & Unclear & Low \\
\hline Herr-Wilbert 2010 & Unclear & High & Unclear & High & High \\
\hline Hohmann 2009 & Low & High & Low & Unclear & Low \\
\hline Jones 1998 & Low & High & Unclear & High & High \\
\hline Jones 2005 & Low & High & Unclear & Unclear & High \\
\hline Kavanagh 2006 & Unclear & High & Unclear & Unclear & High \\
\hline Middleton 2011 & Unclear & High & Low & Unclear & Low \\
\hline Morgenstern 2002 & Unclear & High & Low & Unclear & Low \\
\hline Morgenstern 2003 & Unclear & High & Low & Unclear & Low \\
\hline Nikopoulou-Smyrni 2007 & Unclear & High & Low & Unclear & Low \\
\hline Nir 2006 & High & High & Low & Unclear & High \\
\hline Smith 1999 & High & High & High & Unclear & Low \\
\hline Strasser 2008 & Low & High & Unclear & Unclear & Low \\
\hline Watkins 2013 & Unclear & High & Unclear & Unclear & Low \\
\hline Wojner-Alexandrov 2005 & Unclear & High & Unclear & Unclear & High \\
\hline
\end{tabular}


Table 1: SSEF Elements of Care
1) Awareness Raising
2) Managing risk
3) Information
4) User involvement
5) Assessment - Transient Ischaemic Attack (TIA)
6) Treatment - TIA
7) Urgent response
8) Assessment-Stroke
9) Treatment-Stroke
10) Specialist rehabilitation
11) End of life care
12) Seamless transfer of care
13) Long term care
14) Review
15) Participation in the community
16) Return to work 
Table 2: Summary of Included Studies

\begin{tabular}{|c|c|c|c|c|c|c|c|c|}
\hline $\begin{array}{c}\text { Author, Year; } \\
\text { Country }\end{array}$ & Study Type & Setting & Staff Participants & $\begin{array}{c}\text { Completion of } \\
\text { training }\end{array}$ & $\begin{array}{c}\text { Patient } \\
\text { Participants }\end{array}$ & $\begin{array}{c}\text { Mean } \\
\text { Patient Age }\end{array}$ & $\begin{array}{c}\% \text { Patients } \\
\text { Female; Male }\end{array}$ & $\begin{array}{c}\text { Main } \\
\text { Outcome } \\
\text { Measure }\end{array}$ \\
\hline $\begin{array}{l}\text { Amato 2006; } \\
\text { USA }\end{array}$ & $\begin{array}{l}\text { Pre Post } \\
\text { intervention } \\
\text { observational } \\
\text { (2 separate } \\
\text { convenience } \\
\text { samples) }\end{array}$ & Rehabilitation & $\begin{array}{l}\text { Nurses, N not } \\
\text { stated }\end{array}$ & NS & NS & NS & NS & Patient \\
\hline $\begin{array}{l}\text { Behrens 2002; } \\
\text { Germany }\end{array}$ & $\begin{array}{l}\text { Pre Post-test } \\
\text { intervention } \\
\text { study }\end{array}$ & $\begin{array}{l}\text { Pre-hospital/ } \\
\text { Acute }\end{array}$ & $\begin{array}{l}\text { 345, dispatchers, } \\
\text { paramedics, } \\
\text { doctors and } \\
\text { neurologists }\end{array}$ & NS & 143 & NS & $45 \% ; 55 \%$ & Quality of care \\
\hline $\begin{array}{l}\text { Booth 2005; } \\
\text { UK }\end{array}$ & $\begin{array}{l}\text { Quasi- } \\
\text { experimental }\end{array}$ & Rehab & 26 nurses & NS & 37 & NS & NS & Quality of care \\
\hline
\end{tabular}




\begin{tabular}{|c|c|c|c|c|c|c|c|c|}
\hline $\begin{array}{c}\text { Author, Year; } \\
\text { Country }\end{array}$ & Study Type & Setting & Staff Participants & $\begin{array}{c}\text { Completion of } \\
\text { training }\end{array}$ & $\begin{array}{c}\text { Patient } \\
\text { Participants }\end{array}$ & $\begin{array}{c}\text { Mean } \\
\text { Patient Age }\end{array}$ & $\begin{array}{c}\text { \% Patients } \\
\text { Female; Male }\end{array}$ & $\begin{array}{c}\text { Main } \\
\text { Outcome } \\
\text { Measure }\end{array}$ \\
\hline & $\begin{array}{l}\text { non-equivalent } \\
\text { control group } \\
\text { design }\end{array}$ & & & & & & & \\
\hline $\begin{array}{l}\text { DeLuca 2008; } \\
\text { Italy }\end{array}$ & $\begin{array}{l}\text { Pre Post } \\
\text { observational } \\
\text { cohort study }\end{array}$ & $\begin{array}{l}\text { Pre-hospital/ } \\
\text { Acute }\end{array}$ & $\begin{array}{l}\text { 324, physicians, } \\
\text { nurses, } \\
\text { emergency health } \\
\text { operators, drivers } \\
\text { \& ambulance } \\
\text { technicians }\end{array}$ & NS & 1295 & NS & NS & Quality of care \\
\hline
\end{tabular}




\begin{tabular}{|c|c|c|c|c|c|c|c|c|}
\hline $\begin{array}{c}\text { Author, Year; } \\
\text { Country }\end{array}$ & Study Type & Setting & Staff Participants & $\begin{array}{l}\text { Completion of } \\
\text { training }\end{array}$ & $\begin{array}{c}\text { Patient } \\
\text { Participants }\end{array}$ & $\begin{array}{c}\text { Mean } \\
\text { Patient Age }\end{array}$ & $\begin{array}{c}\text { \% Patients } \\
\text { Female; Male }\end{array}$ & $\begin{array}{c}\text { Main } \\
\text { Outcome } \\
\text { Measure }\end{array}$ \\
\hline $\begin{array}{l}\text { Forster 1999; } \\
\text { UK }\end{array}$ & $\begin{array}{l}\text { Pre Post } \\
\text { intervention } \\
\text { observational } \\
\text { (2 separate } \\
\text { convenience } \\
\text { samples) }\end{array}$ & Rehab & $\begin{array}{l}13 \text { qualified \& } \\
\text { non-qualified } \\
\text { rehab nurses }\end{array}$ & NS & $\begin{array}{l}\text { Pre }=26 \\
\text { Post }=24\end{array}$ & $\begin{array}{l}\text { Pre }=78 \text { Post }= \\
77\end{array}$ & $\begin{array}{l}\text { Pre }=54 \% ; 46 \% \\
\text { Post = 71\%; } \\
29 \%\end{array}$ & Quality of care \\
\hline
\end{tabular}




\begin{tabular}{|c|c|c|c|c|c|c|c|c|}
\hline $\begin{array}{c}\text { Author, Year; } \\
\text { Country }\end{array}$ & Study Type & Setting & Staff Participants & $\begin{array}{c}\text { Completion of } \\
\text { training }\end{array}$ & $\begin{array}{c}\text { Patient } \\
\text { Participants }\end{array}$ & $\begin{array}{c}\text { Mean } \\
\text { Patient Age }\end{array}$ & $\begin{array}{c}\% \text { Patients } \\
\text { Female; Male }\end{array}$ & $\begin{array}{c}\text { Main } \\
\text { Outcome } \\
\text { Measure }\end{array}$ \\
\hline $\begin{array}{l}\text { Forster 2013; } \\
\text { UK }\end{array}$ & Cluster RCT & Acute/Rehab & $\begin{array}{l}54 \text { (approx.) snr. } \\
\text { physiotherapists, } \\
\text { snr. occupational } \\
\text { therapists, snr. } \\
\text { nurses, staff } \\
\text { nurses, consultant } \\
\text { physicians, snr. } \\
\text { speech \& } \\
\text { language } \\
\text { therapists }\end{array}$ & $\infty$ & 928 & 71 & $44 \% ; 56 \%$ & Patient \\
\hline $\begin{array}{l}\text { Frendl 2009; } \\
\text { USA }\end{array}$ & $\begin{array}{l}\text { Pre Post } \\
\text { retrospective } \\
\text { observational }\end{array}$ & Pre-hospital & $\begin{array}{l}\text { Paramedics or } \\
\text { EMT, N not stated }\end{array}$ & NS & 154 & 67 & $56 \% ; 44 \%$ & Quality of care \\
\hline
\end{tabular}




\begin{tabular}{|c|c|c|c|c|c|c|c|c|}
\hline $\begin{array}{c}\text { Author, Year; } \\
\text { Country }\end{array}$ & Study Type & Setting & Staff Participants & $\begin{array}{c}\text { Completion of } \\
\text { training }\end{array}$ & $\begin{array}{c}\text { Patient } \\
\text { Participants }\end{array}$ & $\begin{array}{c}\text { Mean } \\
\text { Patient Age }\end{array}$ & $\begin{array}{c}\% \text { Patients } \\
\text { Female; Male }\end{array}$ & $\begin{array}{c}\text { Main } \\
\text { Outcome } \\
\text { Measure }\end{array}$ \\
\hline $\begin{array}{l}\text { Herr-Wilbert } \\
\text { 2010; } \\
\text { Switzerland }\end{array}$ & Cohort & Rehab & 16 nurses & NS & 44 & 75 & $43 \% ; 57 \%$ & Patient \\
\hline $\begin{array}{l}\text { Hohmann } \\
\text { 2009; Germany }\end{array}$ & $\begin{array}{l}\text { Non- } \\
\text { randomised } \\
\text { controlled }\end{array}$ & $\begin{array}{l}\text { Acute/rehab/co } \\
\text { mmunity }\end{array}$ & $\begin{array}{l}23 \text { community - } \\
\text { based } \\
\text { pharmacists }\end{array}$ & NS & $\begin{array}{l}\text { Control = 165, } \\
\text { Intervention = } \\
90\end{array}$ & $\begin{array}{l}\text { Control = 68, } \\
\text { Intervention = } \\
68\end{array}$ & $\begin{array}{l}\text { Control = } \\
35 \% ; 65 \%, \\
\text { Intervention = } \\
34 \% ; 66 \%\end{array}$ & Patient \\
\hline Jones 1998; UK & $\begin{array}{l}\text { Quasi- } \\
\text { experimental }\end{array}$ & $\begin{array}{l}\text { Rehab/general } \\
\text { wards }\end{array}$ & $\begin{array}{l}59 \text { nurses and } \\
\text { HCAs }\end{array}$ & 59 (100\%) & 38 & 73 & $74 \% ; 26 \%$ & Quality of care \\
\hline Jones 2005; UK & Cluster RCT & Rehab & $\begin{array}{l}\text { All trained nurses } \\
\text { and HCAs, } N \text { not } \\
\text { stated }\end{array}$ & NS & 120 & $\begin{array}{l}\text { Control = 71, } \\
\text { Intervention = } \\
75\end{array}$ & $\begin{array}{l}\text { Control = } \\
50 \% ; 50 \%, \\
\text { Intervention = } \\
63 \% ; 37 \%\end{array}$ & Patient \\
\hline
\end{tabular}




\begin{tabular}{|c|c|c|c|c|c|c|c|c|}
\hline $\begin{array}{c}\text { Author, Year; } \\
\text { Country }\end{array}$ & Study Type & Setting & Staff Participants & $\begin{array}{l}\text { Completion of } \\
\text { training }\end{array}$ & $\begin{array}{c}\text { Patient } \\
\text { Participants }\end{array}$ & $\begin{array}{c}\text { Mean } \\
\text { Patient Age }\end{array}$ & $\begin{array}{c}\text { \% Patients } \\
\text { Female; Male }\end{array}$ & $\begin{array}{c}\text { Main } \\
\text { Outcome } \\
\text { Measure }\end{array}$ \\
\hline $\begin{array}{l}\text { Kavanagh } \\
\text { 2006; USA }\end{array}$ & $\begin{array}{l}\text { Pre Post } \\
\text { intervention } \\
\text { observational } \\
\text { ( } 2 \text { separate } \\
\text { convenience } \\
\text { samples) }\end{array}$ & Acute & $\begin{array}{l}\text { Mixed, N not } \\
\text { stated }\end{array}$ & $\infty$ & 41 & 64 & $55 \% ; 45 \%$ & Patient \\
\hline $\begin{array}{l}\text { Middleton } \\
\text { 2011; Australia }\end{array}$ & Cluster RCT & Acute & $\begin{array}{l}\text { Nurses, N not } \\
\text { stated }\end{array}$ & NS & 1696 & $\begin{array}{l}<65 \\
\text { Control = 28\%, } \\
\text { Intervention = } \\
31 \%\end{array}$ & 更 & Quality of care \\
\hline $\begin{array}{l}\text { Morgenstern } \\
\text { 2002; USA }\end{array}$ & $\begin{array}{l}\text { Quasi- } \\
\text { experimental } \\
\text { comparison }\end{array}$ & $\begin{array}{l}\text { Pre-Hospital/ } \\
\text { Acute }\end{array}$ & $\begin{array}{l}\text { Mixed, N not } \\
\text { stated }\end{array}$ & NS & $\begin{array}{l}1189 \text { (Phase } 1 \text { \& } \\
\text { 2) }\end{array}$ & 72 & $20 \% ; 80 \%$ & Quality of care \\
\hline
\end{tabular}




\begin{tabular}{|c|c|c|c|c|c|c|c|c|}
\hline $\begin{array}{c}\text { Author, Year; } \\
\text { Country }\end{array}$ & Study Type & Setting & Staff Participants & $\begin{array}{l}\text { Completion of } \\
\text { training }\end{array}$ & $\begin{array}{c}\text { Patient } \\
\text { Participants }\end{array}$ & $\begin{array}{c}\text { Mean } \\
\text { Patient Age }\end{array}$ & $\begin{array}{l}\% \text { Patients } \\
\text { Female; Male }\end{array}$ & $\begin{array}{c}\text { Main } \\
\text { Outcome } \\
\text { Measure }\end{array}$ \\
\hline & $\begin{array}{l}\text { group design } \\
\text { with } 2 \\
\text { communities }\end{array}$ & & 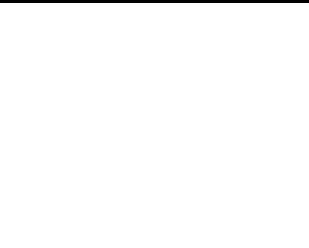 & 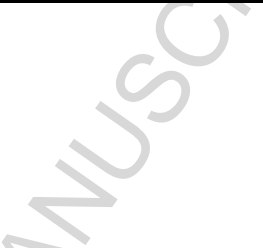 & & & & \\
\hline $\begin{array}{l}\text { Morgenstern } \\
\text { 2003; USA }\end{array}$ & $\begin{array}{l}\text { Quasi- } \\
\text { experimental } \\
\text { comparison } \\
\text { group design } \\
\text { with } 2 \\
\text { communities }\end{array}$ & $\begin{array}{l}\text { Pre-Hospital/ } \\
\text { Acute }\end{array}$ & $\begin{array}{l}\text { Mixed, N not } \\
\text { stated }\end{array}$ & NS & 238 (Phase 3) & 72 & $57 \% ; 43 \%$ & Quality of care \\
\hline
\end{tabular}




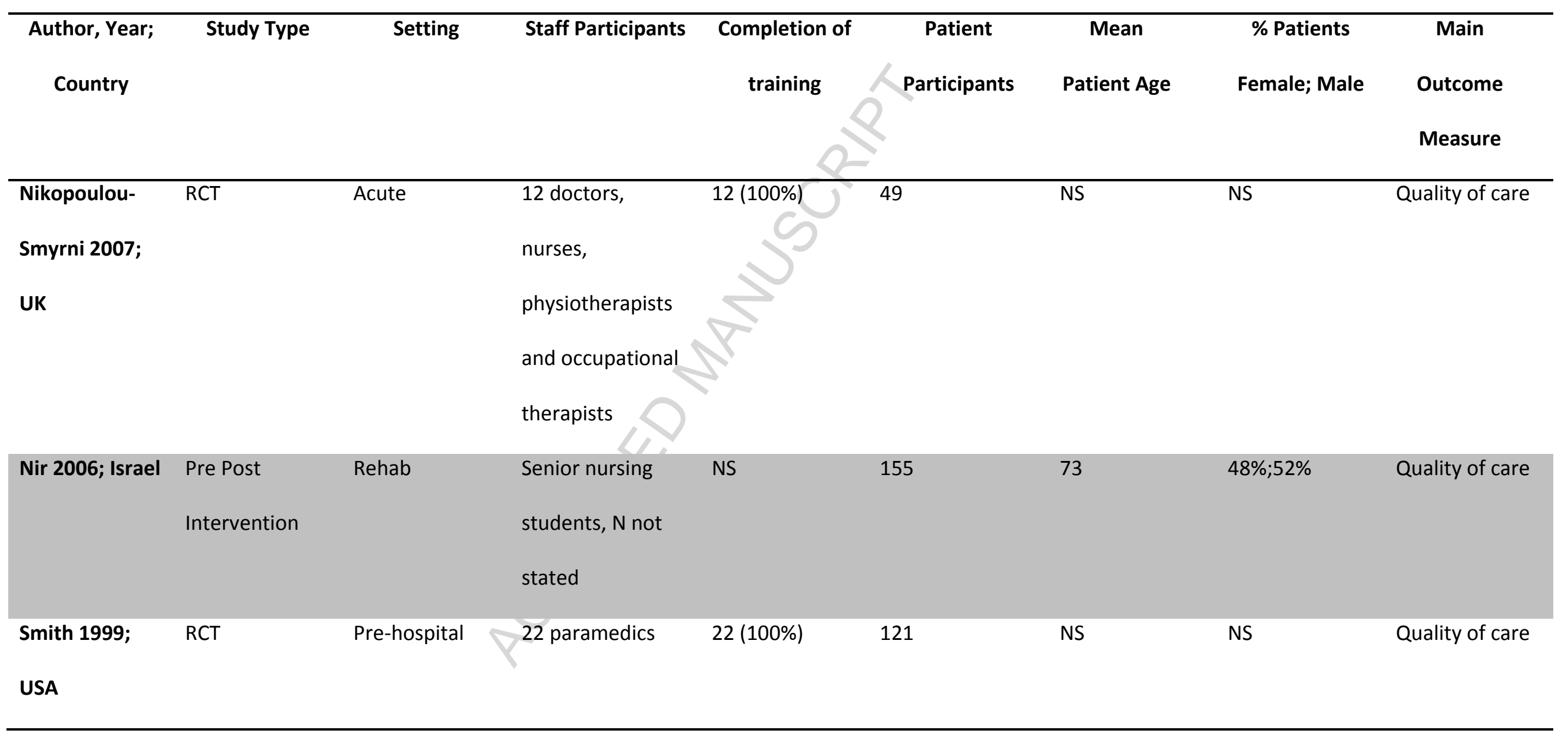




\begin{tabular}{|c|c|c|c|c|c|c|c|c|}
\hline $\begin{array}{c}\text { Author, Year; } \\
\text { Country }\end{array}$ & Study Type & Setting & 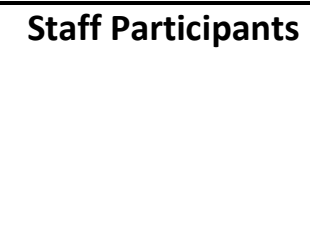 & $\begin{array}{l}\text { Completion of } \\
\text { training }\end{array}$ & $\begin{array}{c}\text { Patient } \\
\text { Participants }\end{array}$ & $\begin{array}{c}\text { Mean } \\
\text { Patient Age }\end{array}$ & $\begin{array}{c}\text { \% Patients } \\
\text { Female; Male }\end{array}$ & $\begin{array}{c}\text { Main } \\
\text { Outcome } \\
\text { Measure }\end{array}$ \\
\hline $\begin{array}{l}\text { Strasser 2008; } \\
\text { USA }\end{array}$ & Cluster RCT & Rehab & $\begin{array}{l}227 \text { rehabilitation } \\
\text { Unit staff: } \\
\text { medicine, nursing, } \\
\text { occupational } \\
\text { therapy, speech } \\
\text { and language } \\
\text { pathology, } \\
\text { physical therapy, } \\
\text { social work. }\end{array}$ & NS & 1374 & 67 & $27 \% ; 73 \%$ & Patient \\
\hline $\begin{array}{l}\text { Watkins 2013; } \\
\text { UK }\end{array}$ & $\begin{array}{l}\text { Interrupted } \\
\text { time series }\end{array}$ & Pre-hospital & $\begin{array}{l}69 \text { emergency } \\
\text { medical } \\
\text { dispatchers }\end{array}$ & 69 (100\%) & 464 & 75 & $52 \% ; 48 \%$ & Quality of care \\
\hline
\end{tabular}




\begin{tabular}{|c|c|c|c|c|c|c|c|c|}
\hline $\begin{array}{c}\text { Author, Year; } \\
\text { Country }\end{array}$ & Study Type & Setting & Staff Participants & $\begin{array}{c}\text { Completion of } \\
\text { training }\end{array}$ & $\begin{array}{c}\text { Patient } \\
\text { Participants }\end{array}$ & $\begin{array}{c}\text { Mean } \\
\text { Patient Age }\end{array}$ & $\begin{array}{c}\text { \% Patients } \\
\text { Female; Male }\end{array}$ & $\begin{array}{c}\text { Main } \\
\text { Outcome } \\
\text { Measure }\end{array}$ \\
\hline Wojner- & Pre Post & Pre-hospital/ & Mixed, N not & NS & 1522 & 69 & $56 \% ; 44 \%$ & Quality of care \\
\hline $\begin{array}{l}\text { Alexandrov } \\
\text { 2005; USA }\end{array}$ & $\begin{array}{l}\text { intervention } \\
\text { observational }\end{array}$ & acute & stated & & & & & \\
\hline
\end{tabular}

N: number; NS: not stated; RCT: randomised controlled trial; snr: senior 
Table 3: Summary of education and training interventions

\begin{tabular}{|c|c|c|c|c|c|c|c|}
\hline Author, Year & $\begin{array}{l}\text { Who Received } \\
\text { Education and } \\
\text { Training }\end{array}$ & $\begin{array}{l}\text { Content of Education } \\
\text { and Training }\end{array}$ & Format of Delivery & $\begin{array}{l}\text { Method of } \\
\text { Delivery }\end{array}$ & $\begin{array}{l}\text { Who Delivered } \\
\text { Education and } \\
\text { Training }\end{array}$ & $\begin{array}{c}\text { Frequency and } \\
\text { Duration }\end{array}$ & $\begin{array}{c}\text { Barriers To } \\
\text { Implementation } \\
\text { Considered }\end{array}$ \\
\hline Amato 2006 & Nurses & $\begin{array}{l}\text { Restraint reduction } \\
\text { and falls }\end{array}$ & Face-to-face & NS & $\begin{array}{l}\text { Clinical nurse } \\
\text { specialist }\end{array}$ & $\begin{array}{l}\text { Ongoing, duration } \\
\text { not specified }\end{array}$ & $Y$ \\
\hline Behrens 2002 & $\begin{array}{l}\text { Mixed (Including } \\
\text { Paramedics/ } \\
\text { technicians, } \\
\text { Dispatchers, } \\
\text { Doctors) }\end{array}$ & $\begin{array}{l}\text { Stroke symptoms, } \\
\text { taking medical } \\
\text { histories, pre-alerting, } \\
\text { stroke as a medical } \\
\text { emergency }\end{array}$ & Face-to-face & NS & $\begin{array}{l}\text { Member of the } \\
\text { stroke project } \\
\text { team }\end{array}$ & $\begin{array}{l}\text { One, } 2 \text { hour session } \\
\text { (repeated) }\end{array}$ & NS \\
\hline Booth 2005 & Nurses & $\begin{array}{l}\text { Handling and } \\
\text { positioning patients }\end{array}$ & $\begin{array}{l}\text { Face-to-face } \\
\text { lectures, videos, } \\
\text { demonstrations }\end{array}$ & $\begin{array}{l}\text { Didactic \& } \\
\text { Interactive }\end{array}$ & $\begin{array}{l}\text { Senior } \\
\text { physiotherapists } \\
\text { and Occupational } \\
\text { therapists }\end{array}$ & $\begin{array}{l}\text { Two, } 3.5 \text { hour } \\
\text { sessions (repeated) }\end{array}$ & NS \\
\hline
\end{tabular}




\begin{tabular}{|c|c|c|c|c|c|c|c|}
\hline Author, Year & $\begin{array}{l}\text { Who Received } \\
\text { Education and } \\
\text { Training }\end{array}$ & $\begin{array}{l}\text { Content of Education } \\
\text { and Training }\end{array}$ & Format of Delivery & $\begin{array}{l}\text { Method of } \\
\text { Delivery }\end{array}$ & $\begin{array}{l}\text { Who Delivered } \\
\text { Education and } \\
\text { Training }\end{array}$ & $\begin{array}{l}\text { Frequency and } \\
\text { Duration }\end{array}$ & $\begin{array}{c}\text { Barriers To } \\
\text { Implementation } \\
\text { Considered }\end{array}$ \\
\hline De Luca 2008 & $\begin{array}{l}\text { Mixed (Including } \\
\text { Paramedics/ } \\
\text { technicians, } \\
\text { Dispatchers, } \\
\text { Nurses, Doctors). }\end{array}$ & $\begin{array}{l}\text { Emergency stroke care } \\
\text { pathways }\end{array}$ & $\begin{array}{l}\text { Face-to-face } \\
\text { lectures, videos, } \\
\text { reflective practice, } \\
\text { on-the-job support }\end{array}$ & $\begin{array}{l}\text { Didactic \& } \\
\text { Interactive }\end{array}$ & $\begin{array}{l}\text { Emergency care } \\
\text { pathway co- } \\
\text { ordinators }\end{array}$ & $\begin{array}{l}\text { Multiple sessions, } \\
\text { duration not } \\
\text { specified }\end{array}$ & $\bar{Y}$ \\
\hline Forster 1999 & Nurses & $\begin{array}{l}\text { Pathology, skeletal } \\
\text { knowledge, normal } \\
\text { movement, positioning } \\
\text { upper limb/lower limb, } \\
\text { gait, aids and } \\
\text { appliances }\end{array}$ & $\begin{array}{l}\text { Face-to-face } \\
\text { lectures, videos, } \\
\text { demonstrations, } \\
\text { workshops/group } \\
\text { discussion }\end{array}$ & $\begin{array}{l}\text { Didactic \& } \\
\text { Interactive }\end{array}$ & $\begin{array}{l}\text { Physiotherapy } \\
\text { lecturer and } 3 \\
\text { senior } \\
\text { physiotherapists }\end{array}$ & $\begin{array}{l}\text { Multiple sessions, } \\
\text { duration not } \\
\text { specified (repeated) }\end{array}$ & Y \\
\hline
\end{tabular}




\begin{tabular}{|c|c|c|c|c|c|c|c|}
\hline Author, Year & $\begin{array}{l}\text { Who Received } \\
\text { Education and } \\
\text { Training }\end{array}$ & $\begin{array}{c}\text { Content of Education } \\
\text { and Training }\end{array}$ & Format of Delivery & $\begin{array}{l}\text { Method of } \\
\text { Delivery }\end{array}$ & $\begin{array}{l}\text { Who Delivered } \\
\text { Education and } \\
\text { Training }\end{array}$ & $\begin{array}{c}\text { Frequency and } \\
\text { Duration }\end{array}$ & $\begin{array}{c}\text { Barriers To } \\
\text { Implementation } \\
\text { Considered }\end{array}$ \\
\hline Forster 2013 & $\begin{array}{l}\text { Mixed (Including } \\
\text { Nurses, Doctors, } \\
\text { Physiotherapists, } \\
\text { Occupational } \\
\text { therapists, } \\
\text { Speech and } \\
\text { language } \\
\text { therapists) }\end{array}$ & $\begin{array}{l}14 \text { core carer } \\
\text { competencies }\end{array}$ & $\begin{array}{l}\text { Face-to-face, } \\
\text { lecture, training } \\
\text { CD, manual/ } \\
\text { workbook, } \\
\text { workshops/group } \\
\text { discussions }\end{array}$ & $\begin{array}{l}\text { Didactic \& } \\
\text { Interactive }\end{array}$ & $\begin{array}{l}\text { Members of the } \\
\text { MDT who were } \\
\text { part of the study } \\
\text { implementation } \\
\text { team }\end{array}$ & Two, 1 day sessions & NS \\
\hline Frendl 2009 & $\begin{array}{l}\text { Paramedics/ } \\
\text { technicians }\end{array}$ & $\begin{array}{l}\text { Stroke recognition and } \\
\text { the use of the } \\
\text { Cincinnati Pre-hospital } \\
\text { Stroke Scale (CPSS) }\end{array}$ & $\begin{array}{l}\text { Face-to-face, } \\
\text { videos, } \\
\text { workshops/group } \\
\text { discussion }\end{array}$ & $\begin{array}{l}\text { Didactic \& } \\
\text { Interactive }\end{array}$ & NS & One, 1 hour session & NS \\
\hline
\end{tabular}




\begin{tabular}{|c|c|c|c|c|c|c|c|}
\hline Author, Year & $\begin{array}{l}\text { Who Received } \\
\text { Education and } \\
\text { Training }\end{array}$ & $\begin{array}{l}\text { Content of Education } \\
\text { and Training }\end{array}$ & Format of Delivery & $\begin{array}{l}\text { Method of } \\
\text { Delivery }\end{array}$ & $\begin{array}{l}\text { Who Delivered } \\
\text { Education and } \\
\text { Training }\end{array}$ & $\begin{array}{c}\text { Frequency and } \\
\text { Duration }\end{array}$ & $\begin{array}{c}\text { Barriers To } \\
\text { Implementation } \\
\text { Considered }\end{array}$ \\
\hline $\begin{array}{l}\text { Herr-Wilbert } \\
2010\end{array}$ & Nurses & $\begin{array}{l}\text { Anatomy, physiology } \\
\text { and pathology of the } \\
\text { urinary tract, urinary } \\
\text { incontinence (UI) and } \\
\text { treatments, identifying } \\
\text { risks and signs of UI }\end{array}$ & $\begin{array}{l}\text { Manual/ } \\
\text { workbook }\end{array}$ & & NS & NS & $\bar{Y}$ \\
\hline $\begin{array}{l}\text { Hohmann } \\
2009\end{array}$ & Pharmacists & $\begin{array}{l}\text { Stroke, risk factors, } \\
\text { symptoms, } \\
\text { pharmaceutical care, } \\
\text { secondary prevention }\end{array}$ & $\begin{array}{l}\text { Face-to-face, } \\
\text { workshop/group } \\
\text { discussion }\end{array}$ & NS & NS & $\begin{array}{l}\text { Multiple sessions, } \\
\text { duration not } \\
\text { specified }\end{array}$ & NS \\
\hline Jones 1998 & Nurses, HCAs & $\begin{array}{l}\text { Aetiology of stroke, } \\
\text { factors influencing }\end{array}$ & $\begin{array}{l}\text { Face-to-face, } \\
\text { manual/ workbook }\end{array}$ & Didactic & Nursing lecturer & $\begin{array}{l}\text { Two, } 2 \text { hour sessions } \\
\text { (repeated) }\end{array}$ & $\mathrm{N}$ \\
\hline
\end{tabular}




\begin{tabular}{|c|c|c|c|c|c|c|c|}
\hline Author, Year & $\begin{array}{l}\text { Who Received } \\
\text { Education and } \\
\text { Training }\end{array}$ & $\begin{array}{l}\text { Content of Education } \\
\text { and Training }\end{array}$ & Format of Delivery & $\begin{array}{l}\text { Method of } \\
\text { Delivery }\end{array}$ & $\begin{array}{l}\text { Who Delivered } \\
\text { Education and } \\
\text { Training }\end{array}$ & $\begin{array}{c}\text { Frequency and } \\
\text { Duration }\end{array}$ & $\begin{array}{c}\text { Barriers To } \\
\text { Implementation } \\
\text { Considered }\end{array}$ \\
\hline & & $\begin{array}{l}\text { recovery, MDT role in } \\
\text { rehabilitation }\end{array}$ & 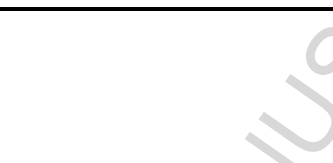 & & & & \\
\hline Jones 2005 & Nurses, HCAs & $\begin{array}{l}\text { Moving, handling, and } \\
\text { positioning of patients }\end{array}$ & $\begin{array}{l}\text { Face-to-face } \\
\text { lectures, manual/ } \\
\text { workbook, } \\
\text { practical } \\
\text { workshops/group } \\
\text { discussion }\end{array}$ & $\begin{array}{l}\text { Didactic \& } \\
\text { Interactive }\end{array}$ & $\begin{array}{l}2 \text { nursing } \\
\text { lecturers }\end{array}$ & $\begin{array}{l}\text { One, } 1 \text { day session } \\
\text { plus two, } 0.5 \text { day } \\
\text { sessions }\end{array}$ & NS \\
\hline Kavanagh & Mixed (Not & American Stroke & Face-to-face, & Interactive & Nurse educators & NS & $\mathrm{Y}$ \\
\hline 2006 & Specified) & $\begin{array}{l}\text { Association (ASA) } \\
\text { guidelines }\end{array}$ & practical, feedback & & & & \\
\hline
\end{tabular}




\begin{tabular}{|c|c|c|c|c|c|c|c|}
\hline Author, Year & $\begin{array}{l}\text { Who Received } \\
\text { Education and } \\
\text { Training }\end{array}$ & $\begin{array}{l}\text { Content of Education } \\
\text { and Training }\end{array}$ & Format of Delivery & $\begin{array}{l}\text { Method of } \\
\text { Delivery }\end{array}$ & $\begin{array}{l}\text { Who Delivered } \\
\text { Education and } \\
\text { Training }\end{array}$ & $\begin{array}{c}\text { Frequency and } \\
\text { Duration }\end{array}$ & $\begin{array}{c}\text { Barriers To } \\
\text { Implementation } \\
\text { Considered }\end{array}$ \\
\hline $\begin{array}{l}\text { Middleton } \\
2011\end{array}$ & Nurses & $\begin{array}{l}\text { Clinical treatment } \\
\text { protocols for fever, } \\
\text { sugar and swallowing }\end{array}$ & $\begin{array}{l}\text { Face-to-face, } \\
\text { lectures, training } \\
\text { CD, protocol, } \\
\text { practical, } \\
\text { on-the-job } \\
\text { support, } \\
\text { workshops/ } \\
\text { discussions }\end{array}$ & $\begin{array}{l}\text { Didactic \& } \\
\text { Interactive }\end{array}$ & NS & $\begin{array}{l}\text { Two sessions, } \\
\text { duration not } \\
\text { specified }\end{array}$ & $\mathrm{Y}$ \\
\hline Morgenstern & Mixed (Including & Increasing awareness & Face-to-face, & Didactic \& & NS & NS & $Y$ \\
\hline 2002 & $\begin{array}{l}\text { Doctors, Primary } \\
\text { care/GP) }\end{array}$ & $\begin{array}{l}\text { of stroke treatment } \\
\text { protocols in the ED }\end{array}$ & $\begin{array}{l}\text { protocol, practical, } \\
\text { feedback }\end{array}$ & Interactive & & & \\
\hline
\end{tabular}




\begin{tabular}{|c|c|c|c|c|c|c|c|}
\hline Author, Year & $\begin{array}{l}\text { Who Received } \\
\text { Education and } \\
\text { Training }\end{array}$ & $\begin{array}{l}\text { Content of Education } \\
\text { and Training }\end{array}$ & Format of Delivery & $\begin{array}{l}\text { Method of } \\
\text { Delivery }\end{array}$ & $\begin{array}{l}\text { Who Delivered } \\
\text { Education and } \\
\text { Training }\end{array}$ & $\begin{array}{c}\text { Frequency and } \\
\text { Duration }\end{array}$ & $\begin{array}{c}\text { Barriers To } \\
\text { Implementation } \\
\text { Considered }\end{array}$ \\
\hline $\begin{array}{l}\text { Morgenstern } \\
2003\end{array}$ & $\begin{array}{l}\text { Mixed (Including } \\
\text { Doctors, Primary } \\
\text { care/GP) }\end{array}$ & $\begin{array}{l}\text { Increasing awareness } \\
\text { of stroke treatment } \\
\text { protocols in the ED }\end{array}$ & $\begin{array}{l}\text { Face to face, } \\
\text { protocol, practical, } \\
\text { feedback }\end{array}$ & $\begin{array}{l}\text { Didactic \& } \\
\text { Interactive }\end{array}$ & NS & NS & $\bar{Y}$ \\
\hline $\begin{array}{l}\text { Nikopoulou- } \\
\text { Smyrni } 2007\end{array}$ & $\begin{array}{l}\text { Mixed (Including } \\
\text { Nurses, Doctors, } \\
\text { Physiotherapists, } \\
\text { Occupational } \\
\text { therapists) }\end{array}$ & $\begin{array}{l}\text { Clinical reasoning in } \\
\text { the assessment of } \\
\text { stroke }\end{array}$ & & NS & NS & NS & NS \\
\hline Nir 2006 & Nursing students & $\begin{array}{l}\text { Chronic and } \\
\text { rehabilitative care, } \\
\text { communication, }\end{array}$ & $\begin{array}{l}\text { Manual/ } \\
\text { workbook, } \\
\text { practical }\end{array}$ & NS & $\begin{array}{l}\text { Member of study } \\
\text { team }\end{array}$ & One, 2 hour session & NS \\
\hline
\end{tabular}




\begin{tabular}{|c|c|c|c|c|c|c|c|}
\hline Author, Year & $\begin{array}{l}\text { Who Received } \\
\text { Education and } \\
\text { Training }\end{array}$ & $\begin{array}{l}\text { Content of Education } \\
\text { and Training }\end{array}$ & Format of Delivery & $\begin{array}{l}\text { Method of } \\
\text { Delivery }\end{array}$ & $\begin{array}{l}\text { Who Delivered } \\
\text { Education and } \\
\text { Training }\end{array}$ & $\begin{array}{c}\text { Frequency and } \\
\text { Duration }\end{array}$ & $\begin{array}{c}\text { Barriers To } \\
\text { Implementation } \\
\text { Considered }\end{array}$ \\
\hline & & $\begin{array}{l}\text { clinical nutrition, } \\
\text { correct use of } \\
\text { medication therapy. }\end{array}$ & & & & & \\
\hline Smith 1999 & $\begin{array}{l}\text { Paramedics/ } \\
\text { technicians }\end{array}$ & $\begin{array}{l}\text { Stroke anatomy and } \\
\text { physiology, stroke } \\
\text { symptoms, National } \\
\text { Institutes of Health } \\
\text { Stroke Scale (NIHSS) }\end{array}$ & & NS & NS & One, 4 hour session & NS \\
\hline
\end{tabular}




\begin{tabular}{|c|c|c|c|c|c|c|c|}
\hline Strasser 2008 & $\begin{array}{l}\text { Mixed (Including } \\
\text { Nurses, Doctors, } \\
\text { Physiotherapists, } \\
\text { Occupational } \\
\text { therapists, } \\
\text { Speech and } \\
\text { language } \\
\text { therapists, Social } \\
\text { workers }\end{array}$ & $\begin{array}{l}\text { Team working, } \\
\text { problem solving, and } \\
\text { quality of care skills }\end{array}$ & $\begin{array}{l}\text { Face-to-face } \\
\text { workshop, written } \\
\text { action plans, } \\
\text { telephone and } \\
\text { videoconferences. }\end{array}$ & Interactive & $\begin{array}{l}30 \text { Team leaders } \\
\text { (Physicians, } \\
\text { Osteopaths, } \\
\text { Nurses, } \\
\text { Physiotherapists, } \\
\text { Occupational } \\
\text { therapists, } \\
\text { Kinesiotherapists, } \\
\text { Social workers, } \\
\text { Speech and } \\
\text { language } \\
\text { therapists, } \\
\text { Administrators) }\end{array}$ & One, 2.5 day session & NS \\
\hline Watkins 2013 & Dispatchers & $\begin{array}{l}\text { Recognition of stroke, } \\
\text { risk factors, stroke } \\
\text { symptoms, stroke }\end{array}$ & On-line course & Didactic & $\begin{array}{l}\text { EMS trainers } \\
\text { trained to } \\
\text { cascade the }\end{array}$ & One, 2 hour session & NS \\
\hline
\end{tabular}




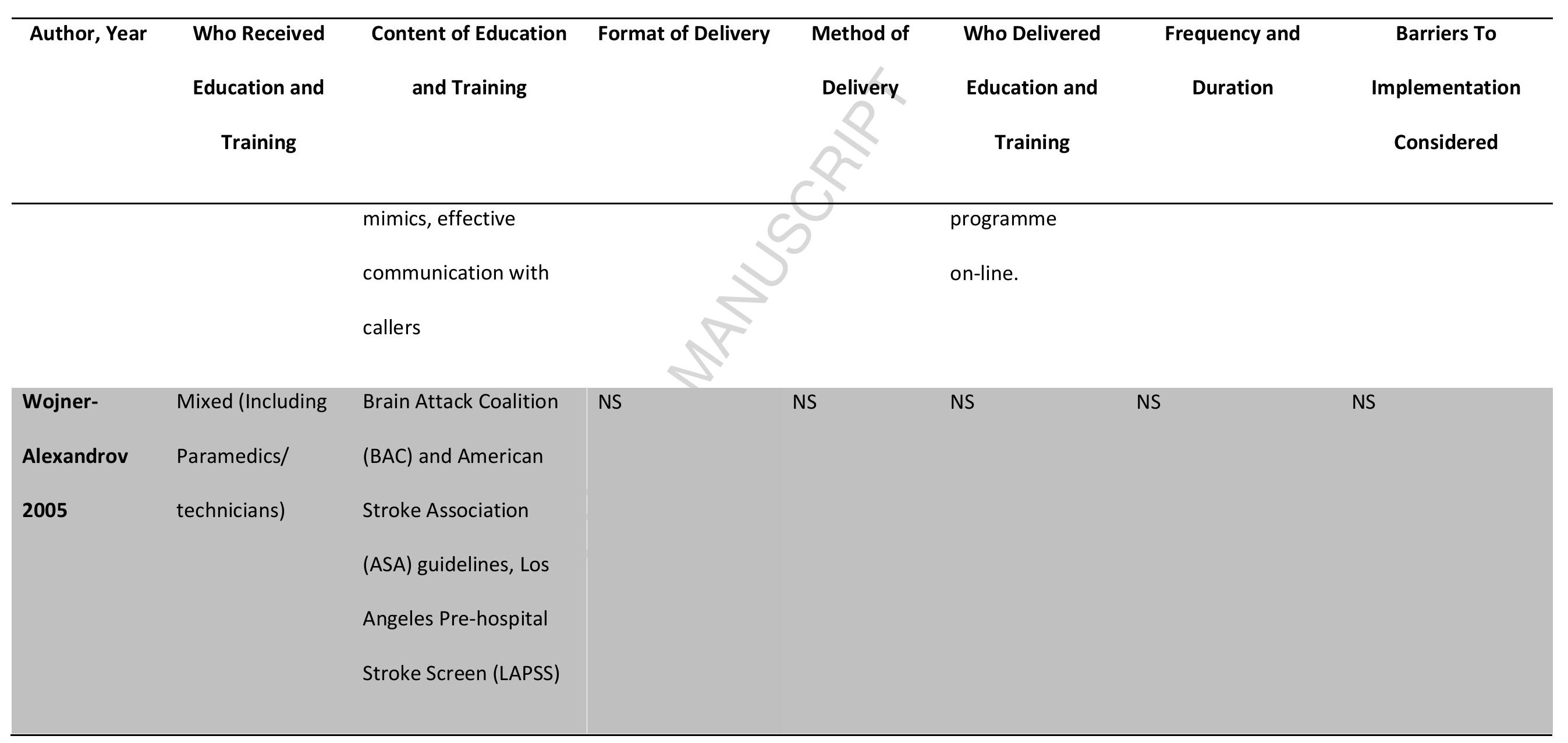


Table 4: Type of staff participating and the number of studies in which they were included

\begin{tabular}{lll}
\hline Staff type & Number of studies & Number of studies where \\
& & staff group taught alone \\
\hline Mixed group & $9^{16,19,20,21,23,26,27,29,30}$ & 0 \\
Doctors & $7^{16,19,20,21,23,26,27}$ & \\
Nurses (including Students \& & & $8^{9,12,14,15,18,22,25,31}$ \\
Health Care Assistants) & $12^{9,12,14,15,16,18,21,22,23,25,27,31}$ & 0 \\
Physiotherapists & $3^{16,21,23}$ & 0 \\
Occupational Therapists & $3^{16,21,23}$ & 0 \\
Speech and Language Therapists & $2^{16,23}$ & $1^{17}$ \\
Pharmacists & $1^{17}$ & 0 \\
Social work & $1^{23}$ & $2^{24}$ \\
Primary Care & $2^{24,26,27}$ & 0 \\
Physicians/ General Practitioners & $2^{19,20}$ & $2^{13,28}$ \\
Paramedics/technicians & $5^{13,26,27,28,30}$ & 0 \\
Dispatchers & & \\
\hline
\end{tabular}




\section{Highlights}

- Education and training can improve outcomes for people who have experienced stroke

- Education and training should be interactive and multi-disciplinary

- Supporting protocols or guidelines are associated with a positive impact on outcome 